\title{
Institutional Components of Economic Security and Their Transformation
}

\author{
Inessa Vasileva*, Natalia Morozova, Artem Evseev
}

\author{
Chuvash State University, Cheboksary, Russia \\ *Corresponding author. Email: inka107@mail.ru
}

\begin{abstract}
The most important process of economic security is the stability and stability of the national economy, which implies the protection of property in all its forms, the creation of reliable conditions and guarantees for business activities, and the containment of factors that can destabilize the situation.

It is obvious that the economic security of the state is determined primarily by the state of productive forces and socio-economic relations, the scale of use of scientific and technological progress in the country's economy, and the structure of foreign economic relations. In this regard, it can be argued that the material basis of economic security of the state is the developed productive forces that can provide expanded reproduction and civilized life of citizens. The economic security of the state is closely linked to the concepts of "development" and "stability" of the economy.
\end{abstract}

Keywords: economic security, national security, public security, human security, economic transformation,

economic security institutions, threats to economic security

\section{INTRODUCTION}

In our era, the degree of satisfaction of national interests largely depends on the role of state institutions as one of the key factors in ensuring the country's economic security. It is not a question of the state once again becoming the sole and all-powerful entity on the territory of the country, although the economy of the economic entity is always dependent on political and social decisions. The identification and study of these circumstances is called institutional changes, which include a set of legal and economic management methods and the task is to identify risks in the field of economic security, develop mechanisms and recommendations to ensure it. National interests should not be ignored, directly trampled on for the benefit of individual corporations, the state or individuals, or their problems solved by harming public interests. Economic security is a state of the economy that ensures guaranteed protection of national interests, socially oriented development of the country as a whole, and sufficient defense potential even under the most unfavorable conditions of development of internal and external processes [1].

If we proceed from the task of ensuring economic security, we can note that institutional changes in the programs of modern economic transformation should include the protection of property rights, ensuring economic stability, effective management of the process of overcoming crisis phenomena in the economy, "creating favorable conditions for economic recovery by improving the most important market institutions" [2, p.15-27].

A competent assessment of the impact of global challenges in terms of changes in the country's macroeconomic indicators allows us to develop mechanisms to minimize their negative impact and to catalyze the institutional transformation of the Russian economic model.

The problems of studying the level of socio-economic development of regions are touched upon in the works of many scientists, such as A. G. Granberg, T. G. Morozov, B. L. Leksin, A. N. Shvetsov, A. L. Gaponenko, V. G. Polyansky, and others.This issue is given an important place, since improving the level and quality of life of the population is impossible in the absence of economic growth, in turn, a low level of social development has a negative impact on economic development.

Issues of economic security were considered in the works of G. S. Vechkanov, O. V. Orlova, M. V. Kuntsman, M. Ya.Kornilov, V. I. Khripun, and others. however, currently there is insufficient elaboration in the direction of quantitative interrelation of factors of institutional and socio-economic development.

\section{MATERIALS AND METHODS}

The theoretical and methodological basis of the research is the works of domestic and foreign scientists, reflecting the problems of economic and national security.

The research is based on system, process and strategic approaches. The application of a systematic approach has ensured the need to consider regions as a set of complex, heterogeneous and dynamic components in the systemforming structure of the economy and its management with a clear justification of the resource, material, organizational, human, financial and investment support for regional development. The study of regional development from the point of view of the process 
approach allowed us to analyze the structure of regional processes, to study the features, forms and directions of relations between processes and their groups. The strategic approach provided justification for the development of mechanisms for self-determination of regional socioeconomic systems in the external environment, focusing the strategic orientation of systems on development, rather than solely on growth, in addition to managerial rationalism associated with the identification of internal reserves of economic growth based on improving the efficiency of the use of all types of resources.

To achieve the required quality of work, the following methods were used: methods of strategic planning; method of expert assessments; methodological approaches to welfare Economics, neo-institutional Economics; method of comparative dynamics; economic and mathematical method; statistical methods; complex-target method.

\section{RESULTS}

Having considered the current situation in the world, it is impossible not to notice the current situation of Russia, which is fraught with a number of threats to its economic system. As a result of the annexation of Crimea, world powers such as the United States and the EU imposed economic sanctions that significantly affected the internal situation of our country as a whole, including the Russian economic system.

The relaunch of defense and security reforms came after European States initially exploited a break with the cold war logic in the 1990s. But the reduction of defense budgets and the accession of Central European countries to NATO were not enough to create a new basis for Europe in the field of defense and security. This is why the most recent period was marked by the need to initiate a deep transformation of defense and security systems in order to adapt to the new strategic context, as well as taking into account the institutional and political framework [3].

The philosophical concept of " security "has evolved: if it once referred to the psychological" serenity "of the sage, and above all the spiritual" salvation "of the believer, the concept of security in our time refers primarily to the security of the state, which today is called "the security of the territory". In accordance with the treaties of Westphalia in 1649 and the treaties of Utrecht in 1713, the great principles of international law were developed. These are three legal principles [4]:

- principle of sovereignty;

- principle of non-interference;

- the principle of balance.

The first principle comes from the treaties of Westphalia that ended the thirty Years ' war. Without creating sovereignty from scratch, these treaties recognize the sovereignty of States at the international level. Equality of sovereignty has never meant that States are endowed with the same capabilities and resources. Legal equality holds very well the inequalities of power.

The principle of non-intervention is formulated in more than one international Treaty. The principle of non- interference has never meant that we are not interested in the life of neighboring States. Non-intervention simply means that after the thirty Years ' war, a person no longer engages in conflicts for religious or ideological reasons. We no longer interfere in the internal Affairs of States because of religion or political system. The principle of non-intervention is a consequence of the principle of sovereignty.

As for the principle of balance, this is primarily a leitmotif of classical political philosophy: Montesquieu notes that the mutual growth of regular troops creates "a state of effort that basically maintains balance, as it wears out the great powers", Rousseau believes that "what really supports the European system is partly a game of negotiation, which almost always balances each other". Voltaire asserts that the European powers "first of all, in wise policy, agree to maintain among themselves, as far as possible, an equal balance of power." Frederick II, praised by Voltaire, notes that "the tranquillity of Europe is based mainly on maintaining this wise balance, by which the superior power of the monarchy is balanced by the combined power of certain other sovereigns". Kant defines international anarchy as "the right to balance between all States that are in effective contact". Finally, Antoine de Jomini, at the heart of the revolutionary upheavals, argues that the policy of European Nations is to "direct all the views of the powers of the continent to maintain a political balance" [5].

European integration took place in several stages. Since the creation of the ECSC in 1957, which United six States until the Treaty on European Union of 27 member States in 2007 (and 28 in 2013), Europe has introduced a configuration that does not correspond to a pyramid Union or plurality in equilibrium, but to the Union of a plurality, that is, "diversity in unity" (in varietate concordia). However, this configuration is more complex legally. The first reason is due to the multiplicity of institutions, mainly four:

- The Brussels European Commission, which votes and implements laws;

- The European Parliament in Strasbourg, which issues opinions on the Committee's proposals and votes on the budget;

- The European court of justice in Luxembourg, which oversees legislation;

- The European Central Bank in Frankfurt, which controls the Euro.

The second reason is related to the delicate legal status of the European Union, which is more than a simple Confederation with defensive purposes against external neighbors. But it is not quite a Federation, that is, a Federal state, although the law of the European Community prevails over the national one.

In any case, regardless of the number or type of mechanisms that affect collective security, different types of macro-political configurations have a common dominant factor: ensuring national security, that is, territorial security, through the collective security mechanism. Collective security is always defined as 
national and territorial security. However, today security is not only national.

In General, there are three levels of security: national, public and human.

The first type of security is "national security", and it refers to what is today called "territory security", that is, protection from external wars. No theorist has a monopoly on this concept, since it is an obsession with classical realism in international relations, even if it is explicitly thematized by Arnold Wolfers, Kenneth Valls, and finally Raymond Aron. This national security is acquired by the game of diplomatic alliances that are reversible in accordance with the geopolitical situation. As Dario Battistella sums up, national security revolves around "the survival of the state, national independence, and territorial integrity" [6].

At present, the threat comes not so much from clearly defined interstate enemies as from transnational or international terrorism, starting with the September 11 attacks in the United States in 2001, in Madrid in March 2004, and in London in July 2005, etc.

However, the concept of national security cannot be reduced to the simple protection of territory. If threats imply hostile intent, then risks include political events, as well as natural, industrial, medical, or technological risks. In any case, if States must ensure their own security, alone or in cooperation, they can also freely "export" their security in a way that ensures the security of other States in order to maintain peace in certain regions of the world. National security means both our own and the security of other States. In most countries, at least, the two dimensions, internal and external, are clearly linked to the three goals that national strategies implement in terms of security and defence: "protection, deterrence, intervention", namely, internal protection, external deterrence with nuclear weapons, and external armed intervention. But in addition to the double dimension, internal and external, that the concept of security covers, the first problem noted is that national security is no longer limited to the protection of territory, but rather signals other types of security, such as social and human.

The new concept is primarily aimed at revealing the concept of security for its realistic belonging and, above all, to increase the types of security: political, economic, environmental, ecological and social. It is in this new direction that social security is promoted, defined as"constancy in acceptable conditions of evolution, traditional models of language and culture, as well as national and religious identity and practice". Any subject of society that has become a political problem can be subject to the process of"securitization". The concept of European social security is primarily concerned with the sensitive issue of immigration. The European organization that precisely manages immigration is the FRONTEX Agency, founded in 2004 and operating since 2005, with its head office in Warsaw. It is through the management of external borders and immigration that the linguistic and economic integration of the immigrant population is ensured.
Finally, there is the concept of "human security", which is the fruit of the work of scientists in the field of international relations, as reflected in the United Nations development Programme (human development Report) of 1994.

National security always requires both human security and social security. There are several types of combinations. The first is national security / social security. The issue of immigration is not only a social problem, but also a national one. Indeed, the social imperative that determines people's ability to speak the national language and find work indirectly allows them to manage migration flows, the terrorist threat, and the arms trade. In General, the control of illegal immigration (social security, economic integration, and identity integration) indirectly protects its citizens (from terrorism, organized crime) and, consequently, ensures national security.

The second combination: human security / national security. At first glance, the issue only concerns human security (illicit drug trafficking, organs and children). But work is also being done on national security through, for example, managing terrorism.

The third combination is human security / social security, since economic policy is both social and human.

In 2017 and 2018, economic growth accelerated in more than half of the world's countries. Over the past two years, developed countries have grown steadily at a rate of $2.2 \%$. Growth rates in many countries have approached potential growth rates, and the unemployment rate in some advanced economies has fallen to historic lows. In developing countries, East Asia and South Asia continued to maintain relatively high growth rates, with growth rates of 5.8\% and 5.6\% in 2018, respectively. Many commodity exporters, especially fuel exporters, are showing a gradual recovery even in the face of price volatility. The consequences of the sharp fall in the commodity market in 2014/15 continue to put pressure on fiscal and external balances and cause high levels of debt. In 2018, the acceleration in growth caused by fiscal measures in the United States of America offset the slowdown in some other major economies and stabilized global economic growth at $3.1 \%$. In 2018, the growth rate of global industrial production and commodity trade gradually slowed, especially in the capital-intensive trade and intermediate products sectors. Key indicators show that economic growth in many countries has weakened in 2019 due to escalating trade disputes, risks of financial pressure and volatility, as well as tensions in geopolitical relations. At the same time, capacity constraints faced by some advanced economies may have an impact on short-term growth [7].

The news figures mask the fragility and frustration of many developing countries and do not reflect the imbalances in economic development around the world. While the global economic Outlook has improved over the past two years, per capita income has declined in several major developing countries. Per capita income in Central, southern, West Africa and Western Asia, Latin America and the Caribbean is estimated to have grown weakly in 
2019. These regions account for almost a quarter of the world's poorest.

Even in areas with strong per capita growth, growth is mainly driven by the main industrial areas, while peripheral and rural areas lag far behind. Although the unemployment rate in some advanced economies is at historically low levels, many people, especially lowincome people, have had virtually no increase in disposable income over the past decade. More than half of the world's population does not have social protection, and livelihood activities have long remained at a high level. Because of this imbalance, the goals of poverty eradication and decent work for all are even further away. Insufficient income growth also poses risks for many other sustainable development goals, as countries need to address infrastructure bottlenecks, improve health, increase human capital, and expand opportunities.

In 2018, trade tensions between the world's largest economies increased significantly, and disputes arising under the WTO dispute settlement mechanism increased significantly. The actions of the USA on increase of import tariffs caused the response. While stimulus measures and direct subsidies have offset most of the direct negative effects that China and the US have suffered, global trade has lost momentum.

Tensions between the major economies of the world has increased, and fares have increased dramatically. The long-term existence of this situation will create serious risks for the prospects of world trade. The global economy may be seriously affected by a slowdown in investment, rising consumer prices, and declining business confidence. Trade disputes can increase financial vulnerability, especially in some emerging economies. Higher import prices, tighter financial conditions, and increased debt servicing costs may reduce industry profits and cause some industries to be in trouble [8].

In 2018, political uncertainty and national vulnerability continued to deepen, leading to frequent fluctuations in financial markets. Investor sentiment was profoundly affected by rising trade tensions, high debt levels, growing geopolitical risks, changes in the oil market, and an expected shift in US monetary policy. In this context, global financial conditions tightened in 2018. In the current uncertain environment, any unexpected development or sudden change in mood could lead to a sharp market correction and a disorderly reallocation of capital. A rapid increase in interest rates and a sharp appreciation of the us dollar may exacerbate the internal vulnerability and financial difficulties of some countries, which will increase the risk of debt problems [9].

Long-term potential vulnerability threatens the sustainability of global economic growth in the financial, social and environmental areas.

Global levels of public and private debt continue to grow. In some countries, huge debt service obligations place a heavy burden on public finances. Generally speaking, as developing countries increase their debts, their productive assets often do not expand accordingly. The large infrastructure gap, degradation of existing capital and its impact on productivity have raised concerns about the long-term sustainability of debt and medium-term productive capacity [10].

The multilateral approach to global decision-making faces serious challenges. There is growing recognition that the benefits of economic integration are unevenly distributed between and within countries. Trade and financial liberalization is considered to exacerbate income and wealth inequality within countries, restrict political space, and in some cases even undermine national sovereignty. The main institutions and agreements of the multilateral system are under increasing pressure. Such pressures have emerged in areas such as international trade, international development Finance, and climate change.

When multilateralism is under threat, international cooperation and governance are particularly important. Many of the challenges set out in the 2030 agenda for sustainable development are global in nature and require collective and joint action to address them. A more inclusive, flexible and flexible multilateral system must be created.

In today's closely connected world economy, internationally agreed rules and institutions are necessary to ensure good market operations, resolve differences, and ensure stability. Therefore, the strengthening of multilateralism is the key to sustainable global development. To be effective, the multilateral system must respond to legitimate concerns and criticism. Effective national tax policies should be complemented by international tax cooperation

Managing the wealth of natural resources requires farsighted policy strategies. The wealth of natural resources must be managed effectively, and a forward-looking strategy formulated for them can create huge opportunities for economic development. Income from the commodity sector can provide important income, support the expansion of education and health opportunities, investment in important infrastructure, the provision of important social security services, and economic diversification. Diversification will increase adaptability and, in many cases, environmental needs. To this end, a broad range of sustainable development strategies should adopt an integrated approach to commodity management, with the key elements of strengthening the system, increasing transparency, developing counter-cyclical policies and making accurate investments in human capital.

Education, employment policies and rural infrastructure are at the heart of reducing inequality. Expanding educational opportunities and improving the quality of education are the keys to overcoming this obstacle. Employment policies, such as raising the minimum wage and expanding social security, will also help improve the standard of living of the poor. Prioritizing rural infrastructure development through public investment in transport, agriculture and energy can also help reduce poverty and narrow the urban-rural divide.

Economic measures have a negative impact on certain sectors of the economy: banking, financial, stock market, etc. But the Russian Federation has allies such as China, Belarus, Kazakhstan, Cuba, Venezuela, India, etc. in 
Addition, the Russian embargo on a number of food categories from the EU, the United States, Australia, Canada and Norway gives Russian companies a chance to become beneficiaries of restrictions on food supplies from countries that have joined the sanctions. The imposed economic restrictions serve as an impetus for the development of domestic production, and hence the institutional transformation of the economic model.

Currently, the Russian economic system faces difficult but achievable tasks: adaptation to the new realities and independent existence relative to international financial centers. At the same time, important importance is attached to the institutional aspects, the formation of a favorable institutional environment through the implementation of significant institutional changes.

\section{CONCLUSION}

In the new business model it is necessary to distinguish mainly the new or changing economic institutions that are being formed:

- inflation targeting;

- targeting public investment in high-tech manufacturing, new mechanisms for the financial market;

- issuing government short-term bonds);

- formation of the Institute of import substitution for the most strategically important industries in the basic areas of the economy.

The functioning of these institutions in terms of their significance is reflected in the context of the basic sectors of the economy: public, real and private. In General, we can conclude that the Russian economy is entering a period of significant institutional changes, which will have a different character from short-term to long-term - for the period up to 2025-2030.

Thus, changing the rules of the game in the global economic system leads to significant institutional changes in the economy of the Russian Federation, which in General contributes to its transformation and, in fact, forced transition to a new business model, in which the most significant are the processes of import substitution, redistribution of investment resources and reorientation of foreign economic relations to new markets.

\section{ACKNOWLEDGMENT}

The reported study was funded by RFBR, project number 20-010-00683.

\section{REFERENCES}

[1] Economic security of Russia: V. K. Senchagov (Eds.), Moscow, 2018, 388 p.

[2] "Program of anti-crisis measures of the Government of the Russian Federation“, Phil. Economic policy of Russia - XXI century, vol. 3, pp. 15-27, 2019.

[3] L.I. Abalkin Evolutionary Economics and "mainstream", Moscow, 2019, 270 p.

[4] V. Ivanchenko "To new social imperatives of Russia“,Phil. Questions of economy, vol. 2, pp. 115117, 2019.

[5] A.N. Klimonova «Main approaches to the study of the concepts of "economic security" and "economic security of the state", Socio-economic phenomena and processes, vol. 8, pp. 54, 2014.

[6] A.M. Mikhailov "Economic and institutional rela tions", Economic science, vol. 5, pp. 48-52, 2017.

[7] D.P. Frolov "Institutional relations in society and economy", Theoretical Economics, vol. 1, pp. 112-116, 2018.

[8] Danilov, T. Ladykova, N. Morozova, and E. Ilyina, "State policy of staffing of global reindustrialization of national economy”, Phil. Journal of advanced research in law and economics, vol. 1-8, pp. 18-22, 2017.

[9] N. Tumanov and N. Urusova, "Impact of economic interests and institutional structures on economic development”, Phil. Bulletin of Chuvash University, vol. 1, p. 245, 2014.

[10] L. Progunova, T. Satsuk, A. Slavin, T. Veynbender, A. Perova, and G. Sokolova, "International standards of the public sector financial reporting in ensuring economic security”, Phil. Revista Publicando, vol. 18-2, pp. 330-340, 2018. 